\title{
Az egyetemes társadalmi-kulturális jelenségek (humán univerzálék) tanításában rejlő lehetőségek az iskola bevezető és kezdő szakaszában
}

A fogalom - amelyet más terminusokkal társadalmi, vagy humán univerzálénak, illetve egyetemes társadalmi-kulturális jelenségeknek is neveznek - a kulturális antropológiából

szivárgott át a neveléstudomány területére, és az emberiség számára nélkülözhetetlen társadalmi jelenségek megnevezésére szolgál (Brown, 2013), amelyek kulturális különbségektól függetlenül szükségszerüen megjelentek és megjelennek minden jelenkori, múlt- és jövóbeni társadalomban,

kultúrában, emberi közösségben. Az univerzálék számos formában és absztrakciós szinten megnyilvánulhatnak. Jelen

lehetnek a mindennapi életben, az emberi viselkedésben, a gondolkodásban és az érzelmekben, az intézményi struktúrákban

és a tárgyi kultúra bizonyos formáiban is (pl. étkezés, öltözködés, lakáskörülmények, családstruktúrák, kormányzat, kommunikáció, szállitás, pénz vagy a gazdasági csere egyéb formái, vallás, hivatás, kikapcsolódás stb.).

\section{Bevezetés}

A neveléstudomány hosszú idő adós a kulturális antropológiában humán univerzáléknak nevezett fogalom értelmezési kereteinek kijelölésével és pedagógiai relevanciájának megállapításával. Szakirodalmi szintézisünkkel ennek a hiányosságnak a megszüntetésére törekszünk. A kultúrantropológia fogalmi rendszerének segítségével meghatározzuk a humán univerzálé fogalmát, és bemutatjuk főbb jellemzőit, megnyilvánulási formáit. Elemezzük a jelenség emberi közösségekben betöltött helyét és szerepét, és rámutatunk arra, hogy az univerzálék milyen vonatkozásokkal bírnak az egyén számára.

Az általános elméleti keretek kijelölését követően részletesen foglalkozunk a fogalom neveléstudományi relevanciájával. A nemzetközi szakirodalomból merített elméleti (társadalomtudományi gondolkodás sajátosságai) és gyakorlati példák által (közlekedési eszközök fejlödése, gyermekkor megélése) világítunk rá arra, hogy a modern társadalomtudományi kutatások által felhalmozott tudás iskolai gyakorlatba történő átültetésére számos lehetőség kínálkozhat kisiskoláskorban; a társadalomismereti tananyag 
közvetítésének és feldolgozásának egyik legalkalmasabb módja a humán univerzálék köré történő elrendezés lehet.

Dolgozatunk kitér a civilizációs témakörök tanításával kapcsolatban felmerülő személyi feltételekre és korlátokra, a pedagógusképzés esetében felmerülő kihívásokra. Összegezzük az univerzálék kutatásához kapcsolódó főbb magyarországi eredményeket, és ráirányítjuk a figyelmet a témában folytatandó további kutatások szükségességére, azok lehetséges irányaira is.

\section{A kulturális univerzálé fogalma és néhány megnyilvánulási formája}

A fogalom - amelyet más terminusokkal társadalmi, vagy humán univerzálénak, illetve egyetemes társadalmi-kulturális jelenségeknek is neveznek - a kulturális antropológiából szivárgott át a neveléstudomány területére, és az emberiség számára nélkülözhetetlen társadalmi jelenségek megnevezésére szolgál (Brown, 2013), amelyek kulturális különbségektől függetlenül szükségszerüen megjelentek és megjelennek minden jelenkori, múlt- és jövőbeni társadalomban, kultúrában, emberi közösségben. Az univerzálék számos formában és absztrakciós szinten megnyilvánulhatnak. Jelen lehetnek a mindennapi életben, az emberi viselkedésben, a gondolkodásban és az érzelmekben, az intézményi struktúrákban és a tárgyi kultúra bizonyos formáiban is (pl. étkezés, öltözködés, lakáskörülmények, családstruktúrák, kormányzat, kommunikáció, szállítás, pénz vagy a gazdasági csere egyéb formái, vallás, hivatás, kikapcsolódás stb.).

Az emberiség két olyan univerzáléját emeljük ki, amelyek meglehetösen széles körben azonosított jelenségeket írnak le, de egységes jelenlétük talán kevésbé tudatosult. Az első példa az univerzum keletkezésére és müködésére vonatkozó világmagyarázat igénye. A világegyetemmel, a világunk szerveződésével, strukturálódásával kapcsolatos értelmezések számos kultúrán átívelő hasonlóságot mutatnak. Az a fajta törekvés, explicit szándék egyesíti a világmagyarázatokat, hogy mindegyik a világ keletkezésére és rendeződésére kíván valamiféle elfogadható magyarázatot adni. Sokféle világmagyarázat létezik, ezek közül vannak olyanok, amelyek mitikus magyarázattal szolgálnak a világ különböző részeiről származó eredetmondák és mítoszok formájában, míg mások tudományos eszközökkel igyekeznek megfejteni a világ keletkezését. A kozmológia - az univerzum egészével, tér- és időbeli szerkezetével foglalkozó tudomány - tudományos eszközökkel próbál választ adni a világ keletkezési körülményeire, s megállapításai meglehetösen egységesnek tekinthetök. (Antweiler, 2015).

A második általános univerzálé - amely csaknem minden társadalomban jelen van - az ember és az állatvilág világos megkülönböztetése, elhatárolása. Antweiler (2015) rámutat, hogy a határozott különbségek legalább négy, kizárólag az emberre jellemző megnyilvánulásban érhetőek tetten. Csak az emberre jellemző viselkedés a tüzgyújtás, egyrészt maguk és környezetük melegítésére, másrészt a fózés kivitelezése céljából. Szintén csak az emberre jellemző a külső megjelenés kisebb vagy nagyobb mértékü megváltoztatása arc-, testfestéssel, tetoválással, torzítással vagy ruházattal. Az antropomorfizáció, vagyis az élettelen tárgyak, illetve jelenségek emberi tulajdonságokkal történő felruházása a gyermekirodalomtól és a rajzfilmek világától kezdve a kisgyermekekkel való mindennapi kommunikáción át a bonyolultabb hiedelemvilágokig számos esetben megfigyelhető (1. Waytz és mtsai, 2014). Végül, de nem utolsó sorban a természeti környezet leképezésére, átalakítására, objektiválására való törekvés, valamint a tárgyiasítás és a tárgyakhoz való kötődés ugyancsak a legáltalánosabb univerzálék közé tartozik. 


\section{Az univerzálékkal kapcsolatos általános megfontolások és gyakori téves elgondolások: individuum, globalizáció, genetikai meghatározottság}

Az univerzalitások minden esetben kultúrahordozó egységekre vonatkoznak (pl. társadalmak, nemzetek, etnikumok) és nem az adott közösséget alkotó egyénekre, tehát nem feltétlenül jellemző az adott közösség minden individuumára. Éppen ez az a specifikuma, ami elkülöníti az emberi fajra jellemző sajátosságoktól. Az általános vélekedéssel ellentétben az univerzálék és az ún. embertulajdonságok (1. Csányi, 2015) nem identikusak, közéjük nem lehet egyenlőségjelet tenni, bár a kettő összefügg egymással.

Az univerzálék nem állandóak és nem is statikus természetűek; megjelenhetnek, új jelentésre tehetnek szert, módosulhatnak, majd el is tünhetnek a történelem során. A globálisan jelenlévő kulturális jelenségek elöidézője minden bizonnyal a világszintű keveredés lehetett, amely csaknem egyidős az emberiséggel. A közvélekedéssel ellentétben, nem a globalizáció indította el a folyamatot, a kezdetetek nagyjából visszavezethetőek a homo sapiens megjelenéséhez és elterjedéséhez. A különböző viselkedési formák és a mentális folyamatok számottevő része abból eredeztethető, hogy őseink bárhová is mentek, kapcsolatba kerültek, konfrontálódtak egymással, és mindennapi életük során - a természeti-környezeti tényezök függvényében - hasonló alapproblémákkal kellett szembenézniük. Mindezek eredményeként egyetemes mintázatok alakultak ki az emberi közösségekben, anélkül, hogy ezeknek lenne bármiféle genetikailag meghatározott alapja.

A pszichológiából jól ismert az ún. IQ-vita az öröklés-környezet meghatározottság kapcsán (1. Vajda, 2002). Antweiler (2015) kiemeli, hogy ugyanez a meddő vita gördít akadályt az univerzálék kutatásának is, bár a probléma ebben az esetben könnyen feloldható. Azt javasolja, hogy a kultúrát - mint központi fogalmat - pusztán csak külön kell választani a hasonlóságok és különbségek típusú felosztástól. Hasonlóképpen, mint a gének esetében - amelyek felelösek lehetnek a hasonlóságokért és különbségekért is -, annyiban lehet a kultúra is felelős s hasonlóságok és különbségek kialakulásáért.

A tudományos és laikus közvéleményben létezik egyfajta merev elgondolás, amely az univerzálékra biológiai alapon nyugvó kulturális felépítményként tekint. Eszerint az univerzálék változatlan, szilárd biológiai alapokra épülnek, amelyek egy-egy specifikus tulajdonsággal bíró változékony, képlékeny réteggel egészülnek ki. Antweiler (2015) rámutat, hogy az efféle érvelés azért félrevezető és téves, mert az univerzálék nem genetikai meghatározottságúak. A közvélekedésben feltehetően a sztereotipizáció miatt alakulnak ki ilyen elgondolások, a kulturális különbségek helyett egyszerübb megoldásnak tünik genetikai hátteret feltételezni.

Ez eddig bemutatott megközelítésekben és értelmezésekben az univerzálék jelenség alapú megközelítése volt a hangsúlyos, és azok az okok, amelyek a kialakulásukhoz vezethetnek, háttérben maradtak, miközben létrejöttükben számos tényező azonosítható. Egy-egy univerzálé kialakulásának hátterében több tényezö is meghúzódhat (Antweiler, 2015).

1. Evolúciós alapon nyugvó pszichés és viselkedési szándékok (pl. nepotizmus)

2. Globális elterjedés (pl. a tüz használata a fözéshez)

3. Egy-egy találmány kohéziós ereje a betöltött funkciója miatt (pl. pénz)

4. A fizika törvényei (nyilak nehezített hegye, jobb/bal irány a közlekedésben)

5. Kombinációs hatások (pl. klikkek, szövetségkötések a szociális színtéren).

A bemutatott felsorolásból is kitünik, hogy az egyetemes társadalmi-kulturális jelenségek kialakulásának okai sokrétüek lehetnek, melyek egymással akár több szálon is összefonódhatnak. 


\section{Klasszifikációs törekvések}

A nemzetközi szakirodalom egyértelműen azonosítható a szándék a különböző kulturális univerzálék kategóriákba sorolására (1. pl. Alleman és Brophy, 2001, 2002, 2003a). A könnyebb átláthatóság kedvéért történő kategorizálás logikus és elfogadható, ugyanakkor önkényes, hiszen a kategóriák száma leginkább a jelenségek percepciós szintjétől függ, így egyesek rövidebb, míg mások (pl. Brown, 1991) lényegesen hosszabb és részletesebb felsorolásokat adnak. Megítélésünk szerint a jelenségek osztályozása az egyén és a közösség viszonyát jellemző általános megközelítésig lehet előremutató.

Az általános, filozófiai és pszichológiai ihletésü megközelítés az egyetemes társadalmi-kulturális jelenségek történeti dimenzióját és a kategorizáció külvilág megismerésében és megértésében betöltött szerepét emeli ki. Eszerint az értelmezés szerint a kulturális univerzálék valójában kategóriák, kategóriarendszerek, amelyek a történelem során felhalmozódó tapasztalati tudás bázisán folyamatosan bővülnek és változnak. Mindez az adott közösség kollektív emlékezete által valósulhat meg, hiszen csakis a közösség emlékezete alkalmas az egyén életén túlnyúló, szájhagyomány útján megörzött emlékezeten túlmutató események rögzítésére (Assmann, 1999).

A megközelítés az univerzalitásokat két nagyobb egységre osztja. Az egyik egységet az emberi tudat univerzális jellegü alapstruktúrái alkotják, amelyek minden humán aktvitás alapjául és keretéül szolgálnak, például a tér (helyszín), idő, szükségletek, gondolkodás. A kategóriák másik egységét - történeti dimenzióból szemlélve - a kultúrák fejlődése hívta életre, és olyan absztrakt kategóriákat foglal magába, mint pl. a társadalom, jó, rossz, igazság, szabadság (Stiopin, 2014). Az univerzálék két típusa feltételezi egymást, különválasztásuk csupán az értelmezés szempontjából lehetséges. E két kategóriarendszer kombinációi az emberi közösségek mindegyikében jelen vannak oly módon, hogy kialakítják egy-egy kultúra/közösség térhez és időhöz, az élet és halál kérdéseihez, a természethez, a munkához, a magánszférához való viszonyulás normáit, megteremtve az ún. sajátos kulturális univerzálék (specific cultural universals) széleskörü bázisát.

Az univerzálék közösségi funkcióinak áttekintését követően lényeges kérdés, hogy a jelenségek milyen vonatkozásokkal bírnak az egyén számára. Hangsúlyoznunk kell, hogy egy közösségen belül az egyének mindig saját szemüvegükön keresztül, a megélt egyéni tapasztalatuk fényében alakítják ki viszonyulásukat a kulturális univerzálékhoz. Az egyén helye és szerepe abban rejlik, hogy a kategóriák által megtapasztalja, megérti és értékeli a körülötte lévő világot (Stiopin, 2014), tehát az egyéni funkciója a társadalmi tér értelmezésében, a jelentéstulajdonításban ragadható meg.

\section{A kulturális univerzálék funkciói és lehetséges típusai}

A szakirodalom - különböző időtávlatokhoz kapcsolódóan - az univerzalitások három funkcióját emeli ki az emberi közösségek életében. Egyrészt az állandóságot képviselik, hiszen ahogyan az előzőkben is láttuk, a humán tudat alapstruktúráinak számítanak minden történelmi korszakban. Másrészt, amennyiben történelmi léptékben, hosszabb időtávlatban tekintünk az univerzalitásokra, akkor az igen változó, sokféle közösségi tapasztalatok és viszonyok szelektáló, szürő funkciója domborodik ki. Kulcsszerepet töltenek be abban, hogy a megélt, átélt tapasztalatok fényében egy közösség számára pozitív, kívánatos elemek emberről emberre, generációról generációra áthagyományozódjanak, míg a hátrányos, nemkívánatos, maladaptív elemek fokozatosan leépüljenek, háttérbe szoruljanak. Harmadszor, a közösség életében aktuálisan jelenlévő univerzalitások, és az azok közötti sajátos kapcsolatok, összefüggések az aktuális korkép formálói és fenntartói 
(Stiopin, 2014). Közremüködnek a kultúrába történő bevezetődés (enkulturáció) folyamatában (Németh, 1997), és támogatja az adott kultúra által elfogadott eszmék, értékek, normák elsajátítását, a nemzeti enkulturáció folyamatát (1. bővebben: Dancs, 2016). Antweiler (2016) az univerzálék alábbi típusait különbözteti meg:

1. Beépült univerzálék (negotiated universals): a globális kultúra elemeinek adaptációja helyi szintekre. Eszmei áramlatok és jó gyakorlatok adaptálása, vagy azok átalakítása, módosítása az egyes társadalmakban.

2. Abszolút univerzálék (true universals): minden ismert társadalomban jelenlévő sajátosságok.

3. Közeli univerzálék (near universals): azok a jelenségek, amelyek számos ismert társadalomban jelen vannak, de nem mindegyikben.

4. Következményes univerzálék (implicational universals): két tulajdonság összefüggése, összekapcsolódása egy adott társadalomban oly módon, hogy amennyiben egy sajátosság jelen van, akkor egy másik hasonló sajátosság is megtalálható. Ennek speciális változataként értelmezhető, ha az eredendően szórványosan, törzsi keretek között meglévő jelenségek az idők folyamán sokkal szélesebb emberi közösségekben is elterjednek.

5. Evolúciós univerzálék (evolutionary universals): a civilizációk egyes találmányai, beleértve az írást, piacgazdaságot, bürokratikus szervezeteket, demokráciát, társadalmi mobilitást, pénzrendszert, társadalmi rétegződést.

\section{Néhány kulturális univerzálé tanórai feldolgozásának lehetősége kisiskoláskorban}

\section{Tantárgyi integráció}

Az antropológiai ihletésű fogalmi és elméleti keretek áttekintését követően tanulmányunk további részében a szintézis igényével mutatjuk be, hogy a kulturális antropológiai, az evolúciós pszichológiai, a történeti és neveléstudományi kutatások által felhalmozott tudás hogyan ültethető át az iskolai gyakorlatba. A nemzetközi szakirodalom szembesült azzal a problémával, hogy az egyes civilizációk iskolai megismertetése iránti igény felmerülése esetén is az európai középpontú, nyugati civilizáció marad a központi elem a legtöbb ország tananyagában, holott ekkor elsősorban nem az európai tapasztalatok megismertetése lenne a cél, hanem a civilizációk evolúciójának tanulmányozása (Sjoquist, 2006). Az európai hagyományokról a világ más kultúráira történő kitekintés, nézőpontváltás során árnyaltabb gondolkodás kialakítására van lehetőség, az összefüggések szélesebb spektruma tárulhat a diákok elé, mindez azonban másfajta módszertani megközelítést kíván. A civilizációs témák tanítása kapcsán a szakirodalomból kétféle megközelítés bontakozik ki.

A hagyományosabb megközelítés (diffusionist model) a tanórai feldolgozás fókuszát azokra a központi civilizációkra helyezi, amelyek kiemelkedö kulturális teljesítményüknek köszönhetően meghatározó szerepet töltöttek be egy adott területen, majd a civilizációk vívmányait a szükebb és tágabb környezet adaptálta, vagy kisebb-nagyobb mértékben átalakítva beépítették mindennapjaikba.

A másik lehetőség a kulturális univerzálékon nyugvó tematikus megközelítés. A feldolgozható témák időtlenek, és ugyanolyan relevánsak napjainkban is, mint 100 évvel ezelőtt, hiszen a lehetséges témák az emberiség kollektív tapasztalataira, a civilizációk azon kihívásaira reflektálhatnak, amelyekkel a történelem során szembesültek (pl. a müvészeti és irodalmi irányzatok, a tudományos és technikai fejlődés, a politikai intézmények és társadalmi szervezetek). Az univerzalitásokhoz kapcsolódó ismeretek 
folyamatosan bővülnek a történeti, pszichológiai, antropológiai kutatások jóvoltából. Azonban a legújabb kutatási eredmények beépülése az iskolai gyakorlatba hosszadalmas folyamat, a feltárt összefüggések gazdag hálózatának megosztásához a közvetítendő tudás magas szintü szintézisére van szükség (Sjoquist, 2006).

Az Egyesült Államokban az iskolázás korai, kezdő szakaszában kitüntetett jelentőséggel bír az univerzalitások tanítása (Alleman és mtsai, 2007). Több eredmény is alátámasztja, hogy a fogalom köré épített tananyag gyermekkorban sikeresen alkalmazható a társadalomtudományi müveltség alapjainak kialakítására. A megközelítés Alleman és Brophy (2001, 2002, 2003a; Brophy és Alleman, 2000, 2002, 2005, 2006, 2008; Alleman és mtsai, 2007) munkássága nyomán terjedt el a neveléstudomány területén. Az univerzálék tanítása egy adott társadalom viszonyrendszerének mélyebb megértését vagy a társadalmak közötti különbségek azonosítását segítheti elő (Banks, 1990; Brown, 1991). Az Egyesült Államokban mindehhez a lehetőségek adottak, hiszen a kapcsolódó ismeretek az iskolázás első éveiben a social studies tantárgy tantervi tartalmainak jelentős részét alkotják. Ennek ellenére több bírálat is érte e tananyagrendező-elv létjogosultságát.

Az egyetemes társadalmi-kulturális jelenségekkel, a világ különböző kultúráival való célzott tanórai foglalkozásokra a 21 . században különösen nagy szükség lenne. A modern technológiai eszközök szabad, korlátlan hozzáférést biztosítanak a világhoz, de mindez önmagában nem elegendő. Megfelelő pedagógusi vagy szülői kontroll hiányában jobb esetben felszínes megértésig, de még gyakrabban csupán téves elgondolásokig jutnak el a gyerekek (Reidel és Draper, 2013), ami magában hordozza a világ más részein elő emberekkel kapcsolatos negatív attitüdök, sztereotípiák felerősödésének veszélyét (Beal és Bates, 2010).

\section{A társadalomtudományi gondolkodás sajátosságai}

Általános konszenzus mutatkozik abban, hogy már a kisiskolás gyerekek is képesek a történések egymásutániságát megérteni ( $\mathrm{pl}$. a közlekedés fejlődésének folyamatát a gyaloglástól a benzinüzemü autókig), miközben a pontos dátumok még semmit sem jelentenek számukra. Hasonlóképpen, megérthetik az életkori sajátosságaikhoz illeszkedő

Leggyakrabban az merül fel kritikaként, hogy a feldolgozandó ismeretkörök iránt alig mutatnak érdeklódést a tanulók, mivel azokat már elsajátították a mindennapi tapaszta-

lataikból, ezért nem is szükséges azokkal foglalkozni

(Larkins és mtsai, 1987; Ravitch, 1987). A szakirodalom több oldalról, számos pon-

ton vitatja és cáfolja ezt az álláspontot, és amellett érvelnek, hogy az a fajta tudás, amit a gyermekek kialakitanak a hétköznapi tapasztalataikból, inkább passziv jellegú, s kevésbé alkalmazható, széles

hatókörú tudás (Brophy és Alleman, 2006). Számos esetben a tanulók tudása a mindennapi élet körülményeinek, eseményeinek a legszembetunóbb, felszíni tulajdonságaira korlátozódik, de nem alakul ki mélyebb megértés arra vonatkozóan, hogy a kulturális és szociális jelenségek hogyan és miért formálódtak az adott módon, vagy milyen mértékben és miért különböznek egymástól egyes kultúrákban. 
egyszerübb történeteket, verbális reprezentációkat - ami a gyakorlatban egy-egy központi személy köré felépített célorientált cselekmény narratíváját jelenti -, miközben még nem állnak készen absztrakt történelmi témák elmélyült, elemző feldolgozására (Alleman és Brophy, 2003b). Ez a sajátos kettősség a társadalomtudományokra és a reál területekre jellemző tudás szerveződésének különbségeivel áll összefüggésben. A kognitív fejlődés Piaget által leírt modellje csak korlátozottan érvényes a humán területeken (Downey és Levstik, 1991). A fogalmi rendszer absztrakciós piramisa a reál területeken meredekebb és többszintü, a fogalomalkotás időben hosszabban elnyúló folyamat, míg ugyanez a piramis a humán területeken alacsonyabb, de szélesebb alapokon nyugszik.

A társadalmi-kulturális, civilizációs témák tanórai feldolgozásánál figyelembe kell venni a kisiskolás diákok gondolkodásának sajátosságait, e téren azonban a diákok gondolkodási korlátaival is szembe kell nézniük a pedagógusoknak. A szakirodalom szerint a gyermekek természetes kíváncsisággal fogadják a társadalomismereti témákat, de hajlamosak arra, hogy a sajátjuktól eltérő kultúrákról, civilizációkról elhamarkodottan nyilvánítsanak negatív ítéletet, alábecsüljék a kultúrák elért eredményeit (Reidel és Draper, 2013). További akadályt jelenthet, hogy a kisiskolás diákok „történelemszemlélete” prezentista felfogású: a múltat az utólagos bölcsesség szemüvegén keresztül szemlélik, és a múlt életkörülményeit vagy történéseit összehasonlítják a jelen viszonyaival. Nem ritkák az afféle kijelentések, hogy a múltban élt emberek ostobák voltak, és a mindennapokban használt technológiáik kezdetlegesek, primitívek voltak (Alleman és Brophy, 2003b). Körültekintő tananyagszervezéssel, a foglalkozások felépítésének precíz megtervezésével már az első és második osztályban is lehetőség nyílhat néhány meghatározó jelentőségü kultúrtörténeti vívmány tanítására és a kronologikus gondolkodás fejlesztésére (Alleman és Brophy, 2003b).

A pedagógusok kétféleképpen is segíthetik a prezentizmus és az ítélkezés háttérbe szorítását. Az egyik lehetőség a történelmi empátia (historical empathy) fejlesztése. E képesség fejlesztésének legfontosabb feladata annak kialakítása a tanulóknál, hogy törekedjenek úgy tekinteni a múltra - a korabeli emberekre és eseményekre - mint az akkor élt emberek, és hogy a cselekedeteket az adott helyszínen és időben véghezvitt adekvát reagálásként értelmezzék. Ebben benne rejlik annak szükségessége is, hogy a gyermekek belássák, a mindennapokban használt eszközök az adott korszak civilizációs csúcsát jelentették (Davis és mtsai, 2001).

A másik lehetőség, ha a tanórák lehetővé teszik a diákok számára, hogy konfrontálódjanak és szembenézzenek sztereotípiáikkal. Ennek az a leghatékonyabb módja, ha a diákok egyidejüleg tanulmányozhatják a saját és más ország/közösség kultúrájának egyegy aspektusát, mert így elérhető, hogy tudás és megértés alakuljon ki a diákétól elérő kultúrá(k)ról (Merryfield, 1998; Merryfield és Wilson, 2005).

Tanulmányunk következő részében két konkrét témakör kapcsán mutatjuk be, hogy a megközelítés milyen lehetőségeket kínál a tanórai feldolgozásra, majd azokat a nagymintás kutatási eredményeket tekintjük át, amelyek a szemléltetett példákhoz kapcsolódnak. A bemutatandó nemzetközi és hazai kutatási eredmények, valamint fejlesztési koncepciók közös jellemzője, hogy az egyén felöl közelítik meg a kérdést, és arra törekednek, hogy az egyéni kategóriák tartalmát mélyítsék, gazdagítsák, vagy pedig azt vizsgálják, hogy a tanulók milyen tartalmakkal töltik meg a különböző kategóriákat.

\section{A közlekedési eszközök fejlödése}

A közlekedés és a közlekedési eszközök fejlődésének tanulmányozása az egyik legalkalmasabb témakörnek bizonyulhat az univerzalitásokhoz kapcsolódó ismeretek gyarapítására, a történetiség megértésének támogatására, a prezentizmus háttérbe szorítására és a történelmi empátia fejlesztésére kisiskoláskorban. Alleman és Brophy (2003b) kiemeli, 
hogy a témakörrel való aktív foglalkozás eredményeként számos lényegi összefüggés megértése érhető el. (1) Aktív tanulási módszerek alkalmazása mellett a diákok megérthetik, hogy az olyan találmányok is, mint a tutaj, vagy a fatörzsből kivájt csónak jelentős elörelépés volt, amit az adott korban elérhető források maximális kihasználása, kreatív módon történő felhasználása tett lehetővé. (2) Tudatosulhat a diákokban, hogy az embereknek a régmúltban kevés közlekedési eszköz állt rendelkezésükre: a közlekedés lassú és nehézkes volt, gyalogosan, lóháton vagy szekéren történt. (3) Elsajátíthatják, hogy az emberek a kezdetektől fogva együtt élnek a természetes vizekkel, a korai civilizációk is vizek mentén alakultak ki (folyami kultúrák), ennélfogva a vízi áruszállítás is gyorsabb ütemben fejlödött, mint a szárazföldi. (4) Felismerhetik azt az összefüggést, hogy a kerék megjelenésével és elterjedésével jobb minőségü utakra volt szükség; megjelentek a szekerek, és új utak létesültek. (5) A gyorsaság - az utazásban és a szállításban - a vasúthálózat kiépülésével jelent meg és terjedt el. (6) Beláthatják, hogy napjainkban sokkal könnyebb eljutni egyik helyröl a másikra, és sokféle közlekedési eszköz közül lehet választani.

\section{A gyermekkor megélése}

Alleman és mtsai (2007) módszertani segédletnek beillő összefoglalást adnak arról, hogy a gyermekkor témája mint kulturális univerzálé milyen lehetséges tematikus csomópontok köré építhető fel. A képzési egység kezdetén például tudatosítható számukra a gyermekkor általános jellemzője, miszerint az első években a gyermekek a világon mindenhol nagyon hasonló testi, viselkedésbeli, intellektuális változásokon mennek keresztül. Ezt követően sor kerülhet az egyedi tulajdonságok (pl. ujjlenyomat, hang, arc, gondolatok, érzelmek stb.) összegyüjtésére. Az emberek között természetesen meglévő különbségek elöítélet-mentes megértéséhez járulhatnak hozzá azok a tananyagrészek, amelyek az öröklődéssel, a kultúrákkal, a környezeti hatásokkal és egyéb olyan tényezőkkel foglalkoznak, amelyek közremüködhetnek az egyediség kialakulásában.

A gyermekkor témakörében a születésnap szintén motiváló tananyagrész lehet. A központi gondolat ebben az esetben aköré építhetö fel, hogy bár minden gyermeknek van születésnapja, az ünneplés formái jelentősen különbözhetnek egymástól, s léteznek olyan kultúrák, ahol nem is tartják számon az emberek születésnapját. Ugyancsak szemléletes tananyag-feldolgozást tesz lehetővé a gyermekek és a munka világának kapcsolata, amely a kulturális és történelmi perspektívába enged betekintést. A tanulók megtanulhatják, hogy a gyerekeknek a történelem folyamán korábban szinte mindig dolgozniuk kellett, de korunk fejlett társadalmaiban már törvények tiltják a gyermekmunkát, s a gyerekeknek iskolába kell járniuk.

Nagyobb egységként szintén ehhez a tematikához kapcsolódhat a játék és szórakozás témaköre, melyhez Alleman és mtsai (2007) több praktikus tartalmi és módszertani ajánlást is megfogalmaznak. A kisiskolások számára az újdonság erejével hat annak felismerése és belátása, hogy (1) a családok életében hosszú időn át szorosan összekapcsolódott a munka és a szórakozás (pl. aratóünnepek); (2) a családok a legtöbb dolgot - köztük a játékokat is - maguk állították elő; valamint (3) a játék és szórakozás csak a 20. században nőtte ki magát üzletággá, de azokban az országokban, ahol az anyagi források korlátozottak, a játékokhoz és a szórakozáshoz való hozzáférés lehetőségei hasonlatosak ahhoz, mint amilyen a mai fejlett országok korai szakaszában volt.

Ami a bemutatott témák módszertani vonatkozásait illeti, szintén számos kézenfekvő megoldás kínálkozik. Például az időszalag közös készítésével színesített tanórák megteremthetik annak lehetőségét, hogy a közlekedési eszközök fejlödése kapcsán mélyebb megértés és szilárd ismeretbázis alakuljon ki. A gyerekeket meg lehet kérni, 
hogy készítsék el saját időszalagjukat, és helyezzenek el rajta egyszerü időbeli dimenziókra utaló címkéket (pl. nagyon régen, régen, vagy napjainkban). Ezt követően különböző korokból származó képek elhelyezésével jól szemléltethető, hogy a közlekedés fejlődése mely emblematikus találmányok köré rendezhető (Alleman és Brophy, 2003b).

A gyermekkor témájához illeszkedően a pedagógusok például megoszthatják tanítványaikkal a játékokkal és a szórakozással kapcsolatos családi történeteiket; szintén használhatnak rajzokkal, fényképekkel kiegészített időszalagot, vagy elmondhatják, hogy eddigi életük során milyen főbb technikai változások zajlottak le. Házi feladatként a nagyszülőkkel, a szomszédokkal vagy a család barátaival folytatott beszélgetések során feltérképezhetik, milyen szórakozási és időtöltési lehetőségek voltak gyermekkorukban, illetve hogyan ünnepelték születésnapjukat.

\section{Az univerzálék kutatásával kapcsolatos neveléstudományi eredmények}

Diákok körében végzett empirikus kutatásokból rendkívül kevés információval rendelkezünk arról, hogy a tanulók hogyan viszonyulnak az egyetemes társadalmi-kulturális jelenségekhez, és mennyire tájékozottak az emberi civilizáció világáról. A diákok iskolai és iskolán kívüli forrásból származó ismereteinek, nézeteinek és attitüdjeinek megismerésére, feltárására irányuló szándék kevésbé jellemző a területen. A rendelkezésre álló kutatási eredmények többnyire tanórai megfigyelésekből vagy kismintás fókuszcsoportos interjúkból származnak. A társadalom- és jelenismereti témákkal kapcsolatos nagymintás kutatások csupán az utóbbi évtizedben jelentek meg. A fejezetben a bemutatott témakörökhöz kapcsolódó nagymintás kutatások fontosabb eredményeit foglaljuk össze.

A tudomány-, technika-, és életmód-történetből vett hétköznapi példák (pl. az öltözködés változásai, különböző korok hajótípusai) helyet kapnak a tanulók történelmi tudatosságának, történelmi szemléletmódjának feltárására irányuló nemzetközi összehasonlító vizsgálatokban (1. pl. az 1995-ös Youth and History projektben). Az ilyen irányú vizsgálatokban az alkalmazott feladatok az általános történelmi fejlődés és az alapvető kronológiai tudás feltárását célozzák (Körber, 1997).

Kinyó (2015) nagymintás online kutatásának $(\mathrm{N}=953)$ egyik feladatában különböző közlekedési eszközök és hírközlési formák időrendbe állítását kérte az 1-6. évfolyamon. A feladatban a sorba rendezendő elemek nem vizuálisan, hanem szöveges formában szerepeltek. Az eredmények szerint a feladat mindhárom iteme esetében az 1. évfolyamos diákok 15-20\%-a már helyes időrendi sorrendbe tudta állítani az egyes technikai vívmányokat, 6. évfolyamon azonban a helyes megoldás aránya egyik feladatelem esetében sem haladta meg az 55\%-ot. A vízi közlekedés és hírközlés vívmányainak időrendi sorrendjére vonatkozó feladatok megoldottságának évfolyamonkénti összehasonlítása azt mutatta, hogy a helyes válaszok aránya a 3-6. évfolyamon stagnált, 45-48\%-os megoldottságnál tetőzött, és a négy évfolyamon szignifikánsan nem különbözött egymástól.

A gyermekkor témájához kapcsolódóan Kinyó és Tóth (2017) egy 5. évfolyamos diákokra kiterjedő nagymintás online kutatásban $(\mathrm{N}=1748)$ arra kereste a választ, hogy a diákok milyen hasonló vonásokat, külső és belső tulajdonságokat társítanak nyolc, a világ különböző részeiről származó, külső megjelenésükben jelentősen eltérő, de hasonló életkorú gyermekekről bemutatott fényképekhez. A feltáró célzattal megfogalmazott kérdésre a tanulók a képernyő alján lévő szövegdobozba gépelhették be, szerintük mi a közös a bemutatott képekben (1. kép). 
Ml a közös az alảbbi kẻpekben? Ird a kẻpek alatti szövegdobozbal
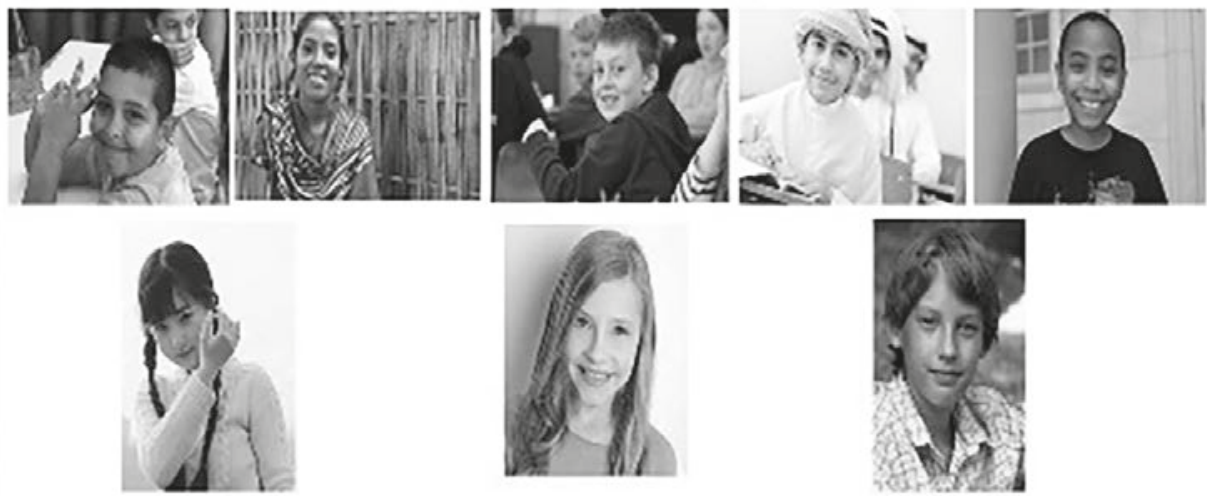

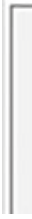

1. kép. A bemutatott képek alapján feltételezett közös tulajdonságok összegyüjtését kérö online feladatoldal

A nyílt végü kérdésre beérkezett válaszok tartalomelemzése azt mutatta, hogy 1697 tanuló (a résztvevők 97\%-a) írt információértékkel bíró, kategóriaváltozóvá alakítható választ. A legtöbb diák (1099 fö, 62,9\%) egy közös tulajdonságot jelölt meg, 445-en (25,5\%) kettő, 106-an $(6,1 \%)$ három közös elemet emeltek ki. Négy, illetve öt közös tulajdonság mindössze 25 tanuló válaszában jelent meg.

Tartalom alapján a válaszokat 10 átfogó kategóriába lehetett besorolni. A legtöbb válasz (782 fö, 44,7\%) a gyermeklét felismerésére vonatkozott, melyet sorrendben az érzelemkifejezés (mosoly) felismerése követett (638 diák, 36,5\%). 307 diák (17,6\%) a bemutatott fényképek alapján az embertársat fedezte fel a fotókon. A válaszok változatosságával kapcsolatban érdemes kiemelni, hogy a gyermeklét és az érzelemkifejezés - a két leggyakoribb kategória - együttesen az előforduló válaszok 65\%-át alkotta, ha pedig hozzászámítjuk a 3. leggyakoribb válaszkategóriát, az embertársat is, akkor az előforduló válaszok lefedettségének 79\%-át kapjuk meg.

A feltételezett lakóhelyre vagy származási helyre utaló válaszok 165 tanulónál $(9,4 \%)$, míg a diákszerepre, tanulószerepre vonatkozó utalások 121 esetben $(6,9 \%)$ jelentek meg. A külső megjelenésre (pl. ruházat, testrészek, érzékszervek) 55 (3,1\%), az életkori hasonlóságra 50 (2,9\%), a bőrszínre 29 (1,1\%), a biológiai nemekre 25 tanuló $(1,4 \%)$ válasza utalt. A diákok válaszaiban többnyire a szemmel látható, külső tulajdonságok említése dominált - erre a válaszkategóriák elnevezései is utaltak -, absztrakt, elvonatkoztatott tartalom kevésbé volt azonosítható, hacsak nem a feltétezett lakóhelyre, származási helyre, illetve a diákszerepre vonatkozó válaszokat nem tekintjük annak (Kinyó és Tóth, 2017).

A nemek szerinti különbségek vizsgálata rámutatott, hogy három tartalmi kategória kivételével a fiúk és lányok percepciója között nincs különbség. Ugyanakkor a három kivételre az jellemző, hogy (1) említésük a lányok körében fordul elő szignifikánsan nagyobb arányban, és (2) kapcsolódnak a humánumhoz és az érzelmekhez (érzelemkifejezés: $\chi^{2}=4,59, \mathrm{p}=0,03$; diákszerep/tanulószerep: $\chi^{2}=7,28 ; \mathrm{p}=0,01$; gyermeklét azonosítsa: $\left.\chi^{2}=24,75, \mathrm{p}=0,00\right)$. A kutatásban tehát megerősítést nyert, hogy az érzelmek 
felismerése és a humánumhoz való odafordulás nagyobb arányban jellemző a lányokra, mint a fiúkra, és ezek a nem szerinti különbségek olyan feladathelyzetben is megmutatkoznak már 10-11 éves korban, amikor a tanulóknak kötetlen szövegalkotásra nyílik lehetőségük (Kinyó és Tóth, 2017).

\section{A társadalomismereti nevelés tananyag-szervezési és oktatási kihívásai hazánkban}

Tanulmányunk korábbi részében bemutatattuk, hogy a nemzetközi szakirodalom milyen válaszokat ad a történelmi, társadalmi-kulturális témák kisiskoláskori tanulás-és tanítás-módszertani kérdéseire. A továbbiakban a magyarországi helyzetet elemezzük a társadalomismereti témakörök kisiskoláskori és későbbi tanításával összefüggésben.

A társadalomismereti nevelés, a demokratikus gondolkodás fejlesztése, valamint a müveltségterület mérése-értékelése az Egyesült Államokban tekint vissza a legrégebbi hagyományokra. John Dewey 20. század eleji úttörő munkásságát követően a müveltségterület szerepe a hatvanas-hetvenes években ideiglenesen megingott ugyan, azonban a '80-as évek közepétől sikerült visszanyernie korábbi meghatározó pozícióját. Az Egyesült Államok komolyan elkötelezett a társadalomismereti nevelés mellett, s gyakran más országok társadalomismeret-oktatásának ügyét is felvállalja, támogatja (Himmelmann, 2006). Hazánkban a rendszerváltást követően indultak meg pozitív irányú változások a társadalomismeret-oktatás egészére vonatkozóan. Kezdetben a terület szerepe és súlya jelentéktelen és bizonytalan volt, a müveltségterület nem integrálódott szervesen az iskolai mindennapok életébe, néhány nemzetközi projekt azonban lendületet adott a változások elindításához.

A kaliforniai székhelyü Center for Civic Education (CCE) meghatározó szerepet tölt be a társadalomismereti nevelés elméleti kereteinek kialakításában, a szervezet egyik máig legmeghatározóbb kiadványának alapvetései több európai (pl. a nagy-britanniai és az európai uniós) kompetenciaértékelési programban is megjelennek (vö. Quigley és Bahmueller, 1991). A keretrendszer gyakorlatba történő átültetése egy több országra kiterjedő társadalomismereti képzőprogram elindításában teljesedett ki: a polgári ismeretek és készségek tanítása a Civitas Egyesület által - négy féléves társadalomismereti nevelés modul formájában - öt magyarországi egyetem tanárképzési programjába is beépült (Setényi, 1996, 2003).

Emellett néhány, az Egyesült Államokban életre hívott, majd Magyarország közreműködésével lezajlott nemzetközi projekt is ösztönzően hatott a változások elindításához. A sikeres törekvések között említhetö például a Jó Polgár (Good Citizen) nemzetközi projekt (1993), amelynek explikált célja a társadalomismereti nevelés elősegítése volt. 1996-ban szintén nemzetközi együttmúködésben (floridai és georgiai partnerségi együttmüködés keretében) valósult meg a „We the people” program mintájára egy magyarországi középiskolai verseny, a Polgár a demokráciában (Citizen in a Democracy). Az Iskolapolgár Projekt (School Citizen) pedig a társadalomismereti nevelés néhány aspektusára, a demokrácia és a tanulói jogok erösítésére koncentrált az iskolákban (Ridley és mtsai, 1997).

A köz- és felsőoktatás szintjein az elmúlt 10 évben bekövetkezett változások a műveltségterület lassú felértékelődésének irányába mutatnak. A müveltségterület helyet kap a kimeneti szabályozás rendszerében. A kétszintű érettségi rendszer bizonyos tárgyakból - beleértve a társadalomismeretet, illetve az ember és társadalomismeret, etikát - a projektérettségi lehetőségét kínálja fel a tanulók számára. Az érettségiző fiataloknak több hónap áll rendelkezésükre, hogy az elözetesen meghirdetett témák közül kiválasszanak egyet, munkájukat tanári útmutatás mellett elkészítsék, azt követően pedig dolgozatukat a szóbeli vizsgán megvédjék (Falus és Jakab, 2005; Stefány, 2008). 
A nemzetközi érettségi tapasztalatainak átültetése, valamint a társadalmi szolidaritás erősítésének szándéka mutatkozik meg a közoktatás rendszerét szabályozó, 2011 decemberében elfogadott köznevelési törvény koncepciójában. A törvény elöírja, hogy az érettségihez minimum 50 óra közösségi szolgálatot kell teljesíteni, s az erről szóló igazolást a 2016. január 1-je után megkezdett érettségi vizsgák esetében kellett elöször felmutatni (Köznevelési törvény, 2011). A nemzetközi érettségi előfeltételeként egyébként ennél lényegesen több, 150 órányi tanórán kívüli, kreatív, sport és szociális segítő tevékenységet kell a tanulóknak teljesíteniük.

Mindemellett a tanulmányban részletezett lehetséges megközelítési mód, a társadalomismereti tartalmak kisiskoláskori tanításának kérdései egyelőre a neveléstudományi kutatások fehér foltját képezik. Alsó tagozaton a környezetismeret lehet a legalkalmasabb tantárgy a társadalmi-kulturális tartalmak közvetítésre - akár az emberismeretbe, a történetiségbe, vagy különböző tematikus témakörökbe ágyazottan -, ugyanakkor egyelöre sem a tantervi tartalmak teljesüléséről, sem a tanórai feldolgozás módszereiről, sem a tanítók céltételezéséröl, fejlesztési elképzeléseikről nem rendelkezünk semmiféle információval, empirikus eredménnyel.

\section{A pedagógusképzés problémái}

A társadalomismereti témák iskolai tanításának kritikus pontja, hogy a tanárképzés $-\mathrm{s}$ itt elsősorban a tanítóképzés - mennyiben tud hozzájárulni a humán univerzálék magabiztos tanításához szükséges tárgyi és tantárgy-pedagógiai tudás kialakításához. Korábbi kutatásokból tudjuk (Mátrai, 1999), hogy a társadalomismereti témákat felső tagozaton vagy középiskolában oktató pedagógusok a föiskolai vagy egyetemi képzésük során nem sajátították el azokat a tárgyi ismereteket és módszertani technikákat, amelyek a témakörök biztonságos tanítását megalapozták volna. A hiányos ismeretek, a módszertan kialakulatlansága és a társadalomismeret bizonytalan helyzete összességében a tanárok bizonytalanságához vezetett. Torney-Purta, Richardson és Barber (2005) az IEA CivEd vizsgálat pedagóguskérdőíveinek metaelemzésében nyolc ország, Ausztrália, Csehország, Dánia, Anglia, Finnország, Magyarország, Norvégia és az Egyesült Államok pedagógusainak tanítási tapasztalatait és önbizalmát hasonlította össze. A politikai témákban (pl. alkotmány, igazságszolgáltatás rendszere) a legalacsonyabb önbizalmat Csehország, Anglia, Magyarország és Norvégia pedagógusai körében tapasztalták, a társadalmi témák (pl. kulturális sokféleség, média) tanításában pedig a magyar pedagógusok számoltak be a legalacsonyabb önbizalamról. Az eredmények szerint a magyar pedagógusok értettek legkevésbé egyet azzal az állítással, miszerint „Egyetértés tapasztalható a társadalomban arról, hogy mit kellene tanítani ezen a területen" (Torney-Purta és mtsai, 2005. 43.). Rendkívül nehéz feladat a tanárképzésbe és a pedagógusok mindennapi gyakorlatába a korunk kihívásaira reagáló nevelési célokat megfogalmazni és új tanítási módszereket bevezetni, különösen, ha a kritikus olvasás fejlesztéséről, a sztereotípiák, elöítéletek, tévképzetek lebontásáról és pozitív irányú változtatásáról (Pittinsky, 2009), vagy a kritikai gondolkodás fejlesztéséről van szó.

A probléma hatványozottan jelen van az ember-és társadalomismeret módszertanában, ahol a progresszívabb módszerek - például a vita, a politikai kérdések megvitatása szubjektív vélemény érzékeltetése nélkül, egy tanóra befejezése a pedagógustól elvárt ,jó válasz" nélkül - olyan készségeket és attitüdöket kíván a pedagógusoktól, amelyekkel korábban nem feltétlenül rendelkeztek, és nem is volt szükségük rá, hogy kifejlesszék azokat (Ridley és mtsai, 1997).

A társadalomismereti témák tanárképzésbe való beépüléséig viszonylag hosszú időnek kellett eltelnie, míg végül a pedagógusképzés átalakításának eredményeként 2008 szeptemberétől lehetővé vált, hogy a NAT Ember és társadalom müveltségterületét 
tanító pedagógusok mesterszintü tanári diplomát szerezzenek az ember és társadalom müveltségterületi tanár mesterszakon. A tanulmányban hangsúlyozott tartalmakat azonban nemcsak az említett tanári mesterszakon lenne érdemes megjeleníteni, hanem a tanítóképzésben, és az új típusú osztatlan tanárképzés pedagógiai-pszichológiai kurzusai között is. Az Antweiler (2015) által pánkulturálisnak megnevezett humán univerzálék közül több - igen különböző absztrakciós szinteken - már régóta hagyományosan jelen van a hazai pedagógusképzésben, mint például (1) az együttmüködés, (2) a korrekt, fair versengés minimuma, (3) empátiára való képesség, (4) a nevelésről vallott felfogások, normák és eszmék, (5) a család mint a biológiai és szociális reprodukció színtere, (6) a serdülőkor és más életkori szakaszok megélése, bevezetési-beavatási rítusok, (7) nemek szerinti különbségek a viselkedésben a serdülőkor alatt. Ugyanakkor ezek mellett léteznek további, világképi jelentőséggel rendelkező univerzalitások is, amelyek beemelése az oktatási rendszer minden szintjére indokolt volna: (1) az emberi mibenlétről (mint organizmus, és mint sajátos minőség) vallott felfogások, (2) korlátozott, önállósággal rendelkező aktorok (pl. képviselet), (3) történelem-felfogások, az emberi kultúra történetisége, (4) kölcsönösség, viszonosság kérdései, (5) metaforákban való gondolkodás, (6) hajlam a nepotizmusra.

\section{Összegzés}

Tanulmányunk központi gondolatmenete egyrészt a humán univerzálék értelmezési keretének kijelölése, másrészt a megközelítés neveléstudományokba történő integrálási lehetőségei köré csoportosult. Az integrálás lehetőségeire a mindennapi pedagógiai gyakorlat, a neveléstudományi kutatások és a pedagógusképzés felől világítottunk rá. A nemzetközi pedagógiai gyakorlatból származó példák részletes bemutatásával kiemeltük, hogy az egyetemes társadalmi-kulturális jelenségek a kisiskoláskori társadalomismereti tananyag adekvát rendezőelvéül szolgálhatnak, és megfelelö kereteket adhatnak az alsó tagozaton a társadalomtudományi müveltség alapjainak kialakításához.

A tanulmányban elemeztük az univerzálék tanításának és tanórai feldolgozásának magyarországi helyzetét. Rámutattunk, hogy a társadalomismereti tartalmak elsajátításának kiemelt időszaka hazánkban az általános iskola felső tagozata és a középiskola, miközben a korszerü társadalomtudományi alapok elsajátítása már az iskola bevezető és kezdő szakaszában is lehetőség nyílhatna. Oktatási rendszerünk alsó tagozaton a társadalomismereti témakörök kisiskoláskori tanítását és elsajátítását jelenleg elsősorban a környezetismeret tantárgy keretei között támogatja, szerepe és súlya azonban nem éri el a kívánatos szintet.

Érintettük a civilizációs témakörök (kis)iskoláskori tanításához szükséges pedagógusi kompetenciákat, hangsúlyoztuk a pedagógusképzés szerepét. Kétségeket fogalmaztunk meg azzal kapcsolatban, hogy a jelenlegi pedagógusképzés megfelelő felkészítést nyújt a hallgatóknak a humán univerzálék magabiztos tanításához.

A tanulmányban részletesen foglalkoztunk a társadalmi-kulturális jelenségek empirikus kutatási lehetőségeivel a neveléstudomány szemszögéből. Rámutattunk, hogy a társadalom- és jelenismereti témákkal kapcsolatos nagymintás empirikus kutatások csupán az utóbbi években jelentek meg, ily módon még számos feltáratlan terület azonosítható. Kevés információval rendelkezünk például arról, hogy a tanulók hogyan viszonyulnak az egyetemes társadalmi-kulturális jelenségekhez, és mennyire tájékozottak az emberi civilizáció világában. A további kutatások feladata lehet annak feltárása, hogy (1) a diákok milyen attitüdökkel rendelkeznek a humán univerzálék kultúránként esetlegesen eltérő megjelenési formáival kapcsolatban, és (2) milyen ismeretekkel rendelkeznek a társadalmi-kulturális jelenségekről. 


\section{Köszönetnyilvánítás, támogatás \\ A tanulmány a Bolyai János Kutatási Ösztöndíj támogatásával készült.}

\section{Irodalom}

Alleman, J. \& Brophy, J. (2001). Social studies excursions, K-3. Book one: Powerful units on food, clothing, and shelter. Portsmouth: Heinemann.

Alleman, J. \& Brophy, J. (2002). Social studies excursions, K-3. Book two: Powerful units on communication, transportation, and family living. Portsmouth: Heinemann.

Alleman, J. \& Brophy, J. (2003a). Social studies excursions, K-3. Book three: Powerful units on childhood, money, and government. Portsmouth: Heinemann.

Alleman, J. \& Brophy, J. (2003b). History Is Alive: Teaching Young Children about Changes over Time. The Social Studies, 94(3), 107-110. DOI: 10.1080/00377990309600191

Alleman, J., Knighton, B. \& Brophy, J. (2007). Social Studies: Incorporating All Children Using Community and Cultural Universals as the Centerpiece. Journal of Learning Disabilities, 40(2). 166-173. DOI: $10.1177 / 00222194070400020701$

Antweiler, C. (2015). Cosmopolitan and pancultural univerals: Our common denomitator and an anthropologically based cosmopolitanism. Journal of International and Global Studies, 7(1) 50-66.

Antweiler, C. (2016). Our common denominator. Human universals revisited. New York: Berghahn Books.

Assmann, J. (1999). A kulturális emlékezet. Budapest: Atlantisz Kiadó.

Banks, J. (1990). Teaching strategies for social studies: Inquiry, valuing, and decision making. New York: Longman.

Beal, C. \& Bates, N. (2010). Crossing Digital Bridges for Global Understanding. Middle School Journal, 41(5), 19-26. DOI: 10.1080/00940771.2010.11461736

Brophy, J. \& Alleman, J. (2000). Primary-Grade Students' Knowledge and Thinking about Native American and Pioneer Homes. Theory \& Research in Social Education, 28(1), 96-120. DOI: 10.1080/00933104. 2000.10505899

Brophy, J. \& Alleman, J. (2002). Primary grade students' knowledge and thinking about Government as a Cultural Universal. Chicago: Spencer Foundation.

Brophy, J. \& Alleman, J. (2005). Primary Grade Students' Knowledge and Thinking About Transportation. Theory \& Research in Social Education, 33. 219-243. DOI: 10.1080/00933104.2005.10473280
Brophy, J. \& Alleman, J. (2006). Children's Thinking About Cultural Universals. Mahwah: Erlbaum. DOI: $10.4324 / 9781410615619$

Brophy, J. \& Alleman, J. (2008). Early elementary social studies. In Levstik, L. S. \& Tyson, C. A. (szerk.), Handbook of research in social studies education. New York: Routledge. 33-50. DOI: 10.4324/ 9780203930229

Brown, D. E. (1991). Human universals. Philadelphia: Temple University Press.

Brown, D. E. (2013). Human Universals. In McGee, R. J., Richard, L. \& Warms, R. L. (szerk.), Theory in Social and Cultural Anthropology. An Encyclopedia. Thousand Oaks: Sage. 410-413. DOI: 10.4135/ 9781452276311.n135

Csányi Vilmos (2015). Íme, az ember. Budapest: Libri.

Dancs Katinka (2016). Kultúra - iskola - nemzeti azonosságtudat. A nemzeti identitás értelmezése és vizsgálatának lehetőségei általános iskolások körében. Magyar Pedagógia, 116(4), 403-425. DOI: 10.17670/mped.2016.4.403

Davies, O. L., Yeager, E. \& Foster, S. (2001, szerk.). Historical empathy and perspective taking in the social studies. New York: Rowman \& Littlefield.

Downey, M. \& Levstik, L. (1991). Teaching and learning history. In Shaver, J. (szerk.), Handbook of research on social studies teaching and learning. New York: Macmillan. 400-410.

Falus Katalin \& Jakab György (2005). A projektérettségi. Az első év tapasztalataiból. Uj Pedagógiai Szemle, 55(10), 3-22.

Himmelmann, G. (2006). Teaching, learning and living democracy. An advanced concept for German „political” education. In Sliwka, A., Diedrich, M. \& Hofer, M. (szerk.), Citizenship education. Theory - Research - Practice. Münster: Waxmann. 45-57.

Kinyó László (2011). Az állampolgári kompetencia mérésének-értékelésének elméleti keretei. In: Csapó Benő és Zsolnai Anikó (szerk.), A kognitiv és affektiv fejlödés diagnosztikus értékelésének lehetöségei az iskola kezdö szakaszában. Budapest: Nemzeti Tankönyvkiadó. 105-147.

Kinyó László (2015). A társadalmi és állampolgári ismeretek online vizsgálata. In: Csapó Benő és Zsolnai Anikó (szerk.), Online diagnosztikus mérések az iskola kezdő szakaszában. Budapest: Oktatáskutató és Fejlesztő Intézet. 97-122. 
Kinyó László \& Tóth Edit (2017). Hogyan látják kortársaikat a gyermekek? Gyermekekröl feltételezett közös tulajdonságok 10-11 éves diákok válaszaiban. In: Kerülő Judit, Jenei Teréz \& Gyarmati Imre (szerk.), XVII. Országos Neveléstudományi Konferencia: Program és absztrakt kötet. MTA Pedagógiai Tudományos Bizottság - Nyíregyházi Egyetem. 429.

Körber, A. (1997). Chronological knowledge, historical associations and historico-political concepts. In Angvik, M. \& Borris, B. (szerk.), Youth and history. A comparative European survey on historical consciousness and political attitudes among adolescents. Hamburg: Körber-Stiftung. 106-152.

Köznevelési törvény (2011). 2011. évi CXC. törvény A nemzeti köznevelésröl. Magyar Közlöny, 162. 39622-39695.

Larkins, A., Hawkins, M. \& Gilmore, A. (1987). Trivial and Noninformative Content of Elementary Social Studies: A Review of Primary Texts in Four Series. Theory \& Research in Social Education, 15(4), 299-311. DOI: 10.1080/00933104.1987. 10505552

Merryfield, M. M. (1998). Pedagogy for Global Perspectives in Education: Studies of Teachers' Thinking and Practice. Theory \& Research in Social Education, 26(3), 342-379. DOI: 10.1080/00933104.1998. 10505855

Merryfield, M. M. \& Wilson, A. H. (2005). Social studies and the world: Teaching global perspectives. Washington: National Council for the Social Studies.

Mátrai, Zs. (1999). In transit. Civic education in Hungary. In: Torney-Purta, J., Schwille, J. \& Amadeo, J. (szerk.), Civic education across countries: Twentyfour national case studies from the IEA Civic Education Project. Amsterdam: IEA.

Németh András (1997). Nevelés, gyermek, iskola. Budapest: Eötvös József Könyvkiadó.

Pittinsky, T. L. (2009). Allophilia: Moving beyond Tolerance in the Classroom. Childhood Education, 85(4), 212-215. DOI: 10.1080/00094056.2009. 10523083

Quigley, C. N. \& Bahmueller, C. (1991, szerk.). Civitas: A framework for civic education. Calabasas: Center for Civic Education.

Ravitch, D. (1987). Tot sociology or what happened to history in the grade schools. American Scholar, 53(3). 343-353.

Setényi János (1996, szerk.). A Civitas Egyesület „Polgári ismeretek és készségek” tanárképzési prog- ramjának követelményrendszere. Budapest: Civitas Egyesület.

Setényi, J. (2003). Civic learning in teacher education: The Hungarian experience. In: Patrick, J. J., Hamot, G. E. \& Leming, R. S. (szerk.), Civic learning in teacher education: International perspectives on education for democracy in the preparation of teachers. Bloomington: ERIC Clearinghouse for Social Studies/Social Science Education. 205-225.

Sjoquist, D. (2006). Teaching world civilizations: Where have we been and where do we go from here? Interdisciplinary Humanities, 23(1), 36-42.

Stefány Judit (2008). A projektpedagógia szerepe az oktatásban. In Falus Katalin \& Vajnai Viktória (szerk.), Kompetenciafejlesztés projektmódszerrel. Budapest: OFI. 11-17.

Stiopin, V. S. (2014). Cultural universals (Anthropological Universal or Human Universals). In Chumakov, A. N., Mazour, I. \& William C. Gay, W. C. (szerk.), Global Studies Encyclopedic Dictionary. Amsterdam-New York: Rodopi. 119-120.

Reidel, M. \& Draper, C. (2013). Preparing Middle Grades Educators to Teach about World Cultures: An Interdisciplinary Approach. The Social Studies 104(3), 115-122. DOI: 10.1080/00377996.2012. 698325

Ridley, H. S., Hidvéghi, B. \& Pitts, A. (1997). Civic education for democracy in Hungary. International Journal of Social Education, 12(2), 62-72.

Tóth Edit \& Kasik László (2010). A szociális kompetencia főbb fejlesztési koncepciói és a pedagógusok szerepe a fejlesztésben. In: Zsolnai Anikó \& Kasik László (szerk.), A szociális kompetencia fejlesztésének elméleti és gyakorlati alapjai. Tanulmánygyüjtemény. Budapest: Tankönyvkiadó. 163-182.

Torney-Purta, J., Richardson, W. K. \& Barber, C. H. (2005). Teachers' educational experience and confidence in relation to students' civic knowledge across countries. International Journal of Citizenship and Teacher Education, 1(1), 32-57.

Vajda Zsuzsanna (2002, szerk.). Az intelligencia és az IQ-vita. Budapest: Akadémiai Kiadó.

Waytz, A., Cacioppo, J. \& Epley, N. (2014). Who Sees Human? The Stability and Importance of Individual Differences in Anthropomorphism. Perspectives on Psychological Science, 5(3), 219-232. DOI: $10.1177 / 1745691610369336$ 
A szakirodalmi tanulmány az egyetemes társadalmi-kulturális jelenségek (humán univerzálék) kisiskoláskori tanításának jelentőségét és lehetőségeit vizsgálja. Célja, hogy széleskörü - a mindennapi pedagógiai gyakorlat lehetőségeitől a pedagógusképzés szerepéig ívelö - áttekintést nyújtson a humán univerzálékon alapuló megközelítés neveléstudományi integrálási lehetőségeiről. A dolgozat a kultúrantropológia fogalmi rendszerének segítségével jelöli ki az univerzálék értelmezési kereteit. Elemezi a jelenség emberi közösségekben betöltött helyét és szerepét, és rámutat arra, hogy egyéni funkciójuk elsősorban a társadalmi-közösségi tér értelmezésében, a jelentéstulajdonításban ragadható meg. A tanulmány a nemzetközi pedagógiai gyakorlatból merített szemléletes példákon keresztül rávilágít arra, hogy a társadalomismereti tananyag közvetítése és feldolgozása leghatékonyabban a humán univerzálék köré történő rendezéssel valósítható meg kisiskoláskorban. A tanulmány elemezi az univerzálék tanításának és tanórai feldolgozásának magyarországi helyzetét, és arra a megállapításra jut, hogy a szerepe és súlya jelenleg nem éri el a kívánatos szintet a környezetismeret tantárgy keretei között. A dolgozat ráirányítja a figyelmet arra, hogy a diákok körében végzett nemzetközi és hazai kutatások, illetve tanórai fejlesztési törekvések föként tartalmi kategóriaként tekintenek a kulturális univerzálékra; a fejlesztések az egyéni kategóriák tartalmának mélyítésére, gazdagítására törekednek, az empirikus kutatások pedig azt vizsgálják, hogy a tanulók milyen tartalmakkal töltik meg az egyes kategóriákat. A tanulmány kijelöli a további kutatások lehetséges irányait, hiányterületeit is. A társadalomismereti tartalmak kisiskoláskori tanításának kérdései egyelőre a neveléstudományi kutatások fehér foltját képezik: a tantervi tartalmak teljesüléséről, a tanórai feldolgozás módszereiről, a tanítók céltételezéséröl, fejlesztési elképzeléseiről nem rendelkezünk információval, empirikus eredménnyel. 